\title{
Search for Justice: Challenges to theology ${ }^{1}$
}

R T H Dolamo

(Univ of the North)

\section{ABSTRACT}

\section{Search for Justice: Challenges to theologyy}

We held the fourth general assembly of the Ecumenical Association of Third World Theologians (EATWOT) in the Philippines from December 10 17, 1996. The theme of the Conference was, "Search for a new, just world order: challenges to theology". Globalization was looked at and critiqued for the impact it has on the poor as understood from the biblical perspective. Economic globalization was found to work in general against poor nations especially women in those countries hence the feminist perspective emphasised during the deliberations. The context of Asia as the poorest of the third-world continents and its religious pluralism necessitated a re-look at theology in general and Christology in particular.

\section{GLOBALIZATION}

\subsection{Description}

Globalization has to do with interaction among people of the world. Such interaction has always been happening in history, through trade, travel, migration, war, exchange of ideas and skills, religion, and culture. Globalization's current understanding, however, is bound up with the growth and expansion of capitalism. Developing from a mercantile slave-trading stage, passing through an industrial-colonizing stage, and reaching today into a corporate-neo-imperialist stage, capitalist globalization ensures unequal development and division of labour, centre-periphery dependency, and one-way flow of world wealth. Competitiveness is its dominant ideology, and through competition it creates polarization, and leads to truncated markets. Not all markets are integrated, but all are ideologically and financially controlled. Present globalization is based on monopolies sustained by the dominant nations. We suffer under cultural, religious, ideological monopolies, as well as under monopolies of technology, finances, access to natural sources, information and communication, and, massive weapons of destruction. We see globalization not as transhistorical reality, but as a matter of social forces, the balance of which can be changed. 


\subsection{Alternatives}

Counter-balancing forces emerge from true interdependency and interaction. Authentic interaction recognizes differences and diversity, in terms of gender, race, ethnic and cultural realities; which are historical realities themselves subject to change and development. There is no universality without recognition of particularities that constitute diversity; and there is no democracy apart from diversity. In creating counter-balancing forces and alternatives, we will base ourselves on and respect certain basic principles:

1.2.1 The intrinsic value of human life and of the whole cosmos, that we revere as Mother Earth.

1.2.2 Due to our preferential option for the poor, we do not accept any action that goes against our people and does not take them into consideration.

1.2.3 Our finite world demands a sustainable development (not one done at the expense of others); we should not destroy resources, people, spiritualities, a common future on the earth.

1.2.4 The inter-relation of true universality and particularities necessitates the articulation of macro and micro realities; what happens at a local level requires global action and reflection, and vice versa.

1.2.5 New criteria, rationalities, and paradigms are present in our praxis. Imagination, affectivity, symbolic action, are becoming most important in our dialogue and thinking. May we always remember that poverty, gender, race, ethnicity, culture, religion, are permanent elements in our theory and practice.

1.2.6 Solidarity is an ethical principle of interaction, based on equalization of power, mutuality. Solidarity is also a historical project with specific programmes, methods, and with liberation as its goal.

\section{SEARCH FOR A JUST WORLD}

On a fresh, beautiful morning of our Assembly, the Asian delegates organized a moving worship. A Korean woman theologian reminded us that "rice is heaven", and this holy gift was placed on our hands and joyfully 
consumed. Then we heard messages from India, Sri Lanka, Indonesia and other people, and acknowledged each other with "shakti" (creative energy). From earth and heaven we received strength and courage to continue our quest for life.

\subsection{Context}

In the context of globalization, the exclusion of marginalized persons and regions of the world, and the feminization of poverty, are major phenomena. We also have to take account of counter-balancing forces and alternatives, some of which we have already mentioned. In many different contexts, where there are common problems and also shared commitments, we have been doing our theological work.

Capitalist globalization both integrates and excludes. It increases imbalances, widens gaps, creates polarization and destabilization, deepens poverty, escalates violence, and increasingly marginalizes and degrades women and children, and all the poor who are the greater part of humankind. The forces that control globalization are powerful but hidden. The world it fashions is profoundly warped and unjust. It is an illusion, nurtured by the capitalist system, that the excluded and the impoverished can catch up by following its logic.

\subsection{A tireless, perennial quest}

What is required is to consolidate counter-forces controlled by the people and their elected institutions.

Concrete counter-forces have never been wholly absent in human history. During our exposure programme (preceding our sessions), some of us visited a farm. A peasant woman, referring to the abuse of emigrant Filipina workers, burst into tears and wept over their degradation. These tears are people's search for a just world. These tears are compassion and protest. They represent God's grief over the ruin of God's daughters. They surely represent the search of the deprived and despised masses - in many countries - for a human world.

The search is not new. The code of Hammurabi, for instance, with its provisions concerning prices, wages, taxes and rights, is an attempt to secure justice for all. More than a thousand years later, the Buddha worked for a new society marked by truthfulness, simplicity, non-violence, compassion and respect for life. Confucius based his social vision on sincerity in private and public conduct, and on the pursuit of what is right and not of what will pay. Plato showed a penchant for common ownership of property as the necessary basis of a finer social order. 
The many slave revolts, from the days of Spartacus, through the consistent resistance of Native Americans, of Afro-Americans, and people's resistance to conquest and colonization, to anti-apartheid and antifascism movements (say in Vietnam, the Philippines, India, South Africa, Nicaragua, Cuba, Angola), are some of the links in the same search for a new world. So are the pro-democracy movements, the struggles of indigenous people everywhere to defend or win back their land, liberty and culture. So too are the ecological movements, women's movements, peasant and fish workers agitations, and the cry and restlessness of the poor. The utopian thought in the West, new proposals like the New International Economic Order (NTEO), new ventures like the World Order Model Projects (WOMP), new ownership patterns worked out in the Scott Bader Commonwealth, are all part of humankind's tireless quest for a global set-up in which life could be lived together in dignity and friendship.

\subsection{Biblical Witness}

The Bible from Genesis to Revelation ${ }^{2}$ is a witness to the same search. Opening with the picture of a world of lights and shadows, of blessings and curses, it leads towards a new heaven and a new earth where all is life, light, liberty and togetherness. The Abraham story affirms the primacy of the person above things, and points to a future which shall be compassion and solidarity in righteousness. The Exodus is a struggle for a new order of things beyond genocide and slavery - a fight initiated by a group of women and carried through by the entire Israelite group. The Bible records the successful struggle of five girls for inheritance rights ${ }^{3}$, and the revolt of the masses against royal oppression 4 .

In general, the Old Testament ${ }^{5}$ evinces an abiding concern for the rights and the well-being of the weak: the widow, the orphan, and the foreigner. The prophets ${ }^{6}$ are particularly strong voices of protest against oppression, of criticism of prince and priest, and of hope of a new world of prosperity and peace for the poor and the just.

Jesus presents his search for a new earth under the symbol of the Basileia of God, offered to the poor and concretely realized in healings, feedings, exorcisms, fellowship meals with outcasts, entrusting of significant leadership roles to women, re-interpreting Sabbath and purity laws, and subverting entrenched tradition in favour of freedom and life ${ }^{7}$. Jesus taught a prayer which calls for transformation of the earth, through the coming of God's Basileia and the sharing of food, forgiveness and security ${ }^{8}$. Striving for God's Basileia and God's justice is the path to the new; its law of love transcends ethnic, cultural, and credal boundaries; it is a law having regard to human persons and their sufferings and needs. 
Jesus had definite views about wealth, its purpose and meaning. It was his inspiration and the dreams gifted by the Spirit that led early Christian' groups to organize themselves as a sharing community at all levels: of faith, spirituality, as well as material goods. This was the lifestyle which continued all around the Mediterranean sea right into the fourth century, when it was undermined by the Church's surrender to the Empire and its manners and mores. The memory, however, of wealth-sharing lived on in the Church, in the teaching of many Christian writers, in the monastic and religious formations, and in several revolutionary movements, Christian and other, from the Middle Ages to modern times.

\subsection{Challenges to Theology}

We now bring the following challenges to theology in search for justice and full humanity.

2.4.1 Theology stands called upon to explore the meaning of the perennial quest we have outlined. What anthropology (or understanding of the human) is involved, and what theology is implied? What depth-structures and orientations of the human heart are indicated? What are the consequences for human relationships, and for the organization of society?

2.4.2 Is there a connection between the early church's experience of communitarian life and its deepening insight into New Testament data which blossomed into a Trinitarian faith? That is, the understanding of the ultimate source-and-goal reality as a sharing community? What would be the social imperatives, possibilities, and promises of such a view/ experience of the Ultimate? Could we not say that our lack of experience of authentic community life has tended to reduce the profound poetry of the Trinity into a childish mathematical enigma?

2.4.3 Is it really possible to believe in a Triune God and to share the Eucharist and the Lord's prayer, and yet be rigidly individualistic in matters economic and social? We need a socio-theological critique of individualism which is a mainstay of capitalist ideology and culture. We need a reaffirmation of the inter-relatedness, the inter-dependency, and the social character of all human wealth, insights and achievements, so that exclusivism, privatism, and patent-claims will be seen for what they really are: errant suppression of large and vital truths concerning earthly existence. 
2.4.4 We need therefore a theology of human solidarity and interdependence with a shared earth and a common destiny; within a plurality of perceptions, symbols, artistic expressions, and life-experiences; within a dialectic between the local and global, the small and the big.

2.4.5 What could be the theological significance of the egalitarian, cooperative culture which indigenous people developed the world, and lived for thousand of years before the coming of "civilization"? Is not theology bound to explore afresh the relation between the socialist dream and the implications of faith in one God creator of all people? Socialism has of course failed but capitalism per se has also not relieved the suffering of the poor. Theology must seriously interrogate both systems with the view to incorporate the positive elements found in both of these economic systems.

2.4.6 A socio-theological critique of capitalism, globalization and neocolonialism, of its divisive and destructive character, of its consumerist culture and of its worship of wealth and weapons, is a necessity.

2.4.7 Integral to that work will be a critical examination of really existing "democracy". The word has acquired a magical charm which hides its ambiguities, ugliness and contradictions. What does democracy mean when the system rests on slavery and on slave/cheap labour by which a small group of the powerful benefit and celebrate "freedom"? What does it mean when its rituals are practised and cherished at home while the same powers indulge in imperialist conquests and colonial oppression/exploitation abroad? Or, when the system flourishes at home while supporting dictators and fascists abroad? Is democracy essentially bound up with deep inequalities? Is authentic political democracy at all possible without economic democracy? What would be the anthropological-theological basis of democracy?

\section{THE GENDER PERSPECTIVE}

During the worship led by women delegates, four persons (each with two candles in their hands) invited us to acknowledge inner light in a cosmic movement; we listen to the Magnificat ${ }^{10}$, and - together with Mary praised God who raises the humble and liberates all; finally we receive a Shibashi blessing coming from the Earth towards each one of us and towards everyone in the Assembly. This blessing moved all the delegates 
to consider - once again - the gender perspective; but this time in a very strong call within EATWOT's existence.

The struggle within EATWOT to understand and embrace women's liberation theologies has as its source patriarchal ideology and structures, that have seen theology as being done only by men and from a male perspective. When EATWOT's women members begin to do theology they introduce not only a different hermeneutics, but also a different epistemological paradigm - a different way of seeing and understanding reality.

When women talk about feelings and affectivity, about sexuality and the body, about hungry children, about single women head of families, about violence against women, about ecology, many men of EATWOT seem to think that those are not structural problems. Women insist that those are structural issues that have an impact on daily lives of the poor at the micro level and are perpetuated in ideologies and institutions at the macro level. Many men of EATWOT dismiss what women of EATWOT say as non-important, as peripheral, and continue to classify it as having to do with "women issues", and make the women responsible for such issues. No matter how often women of EATWOT explain that gender issues are intrinsical to all issues, men of EATWOT continue to ignore it.

In order to get the attention of EATWOT men, the women walked out of a plenary assembly, hoping that the men would deal with the questions women keep raising.

\section{REVIEW OF THE WORK DONE (1992-1996)}

Halfway through the Assembly, Latin American delegates led us in a worship of bonding, addressing the four directions of the Earth, that we all gladly kissed. Then, each person in her/his own language prayed: Come, Spirit of Life. Afterwards, we were informed of the good work in two general concerns. The Women's Commission has been very active in the four regions; and it asks that dialogue on gender characterizes the next five years of EATWOT. A series of intercontinental Theological Dialogue have taken place, in spite of the many difficulties in listening and learning from each other; the proposal of this commission has been that gender, race, and African realities, be our priorities. These concerns and insights seem prompts of the Spirit, present among us.

The main purpose of EATWOT was to create a context for intercontinental dialogue among theologians of Asia, Africa, Latin America, and - more recently - US minorities. After the organizing Assembly at 
Dar-es-Salaam (1976), EATWOT held three major international Conferences: a pan-African conference in Ghana (1977), an Asian conference in Sri Lanka (1979), and a Latin American conference in Brazil (1980). Its fifth international conference - and first intercontinental assembly - met in New Delhi (1981). Dialogue was difficult; we were not able to listen to each other. The women present shocked the men into recognizing that women's experiences and wisdom must be taken seriously in EATWOT's work. In 1983 we met in Geneva for a dialogue with first world theologians, but the gap that separated our own theologies from each other was not bridged. Attempt at dialogue during our second assembly in Mexico (1986) was also a failure. Each continent clung to its own analysis and spoke to itself.

At the third assembly in Nairobi (1992), the issue of intercontinental dialogue was raised as EATWOT's original purpose. So the assembly created a commission on intercontinental dialogue. The commission met in New York (1992) and planned three dialogues, focusing of "theological methodology", "Christology and popular religion", and, "women's experience of the sacred". Our meeting proceeded to consider the three themes of intercontinental dialogues.

\section{THEMES}

\subsection{Methodology}

In methodology, the meeting considered four central aspects. The first one is the connection between race and politics of oppression, that has been experienced in Third World communities. The second focuses on the inappropriateness of treating indigenous people as part of a large class of poor. The other aspect is the colonization of our language, to the extend that our use of language is shaped by the colonizer. The other important consideration is marginalization of women ${ }^{11}$.

As Third World theologians confronting the new realities of globalization, the challenge is to developed holistic methodologies with a special emphasis on cultural analysis together with economic and political analysis. Such methodologies must continue to address the challenges of race, gender, class, ecology, and the struggle of indigenous people. There is a need for a new theological paradigm ${ }^{12}$, one that embraces the total reality of our different contexts in the Third World. 


\subsection{Christology}

Christology, like the rest of theology, must be remade, rewritten, in terms of new realities. It will not do to repeat the old. We have to wrestle with and dismantle our colonial theological baggage. Every work of theology involves a new vision. In remaking Christology in Asia, two realities will be decisive: (a) Asia's religious pluralism, and (b) Asia's poor. These are the two poles for doing Christology in Asia.

\subsubsection{Religious Pluralism and Christology ${ }^{13}$ in Asia}

Asia is the birthplace of most of the major religions of the world. These many religions have moulded the life of millions upon millions of people for many long centuries, and influenced their philosophies and cultures. Christian missionaries in general came not to seek, listen, or learn or share mutually, but to convert, conquer, and dominate. The traditional religions were seen as devil's trap. Dialogue was avoided for fear of syncretism. Revelation in Jesus was held to be absolute, unrepeatable, exclusive.

Today we are aware that religious pluralism is the response of the finite to the Infinite. God cannot be experienced in one way only. The different religious symbols are different approaches to the Divine. The many religions are a challenge to one another. Through dialogue they can impact and enrich each other. The pluralistic situation is a chance for all believers to live their religion without arrogance and our relativism. The others may have some truth meant also for us. Christian truth must therefore be articulated and exegesis done in dialogue with other religions.

\subsubsection{The Asian Poor and Christology}

The majority of the world's poor are in Asia, and are believers in other religions. Now there can be no Christology without reference to the poor. Jesus identifies with the poor, because God is biased in their favour. But to identify with Asia's poor is to identify with Asia's non-Christian masses. That makes Asian Christology complex. What is the mode of his presence among them? How are we to articulate it without having recourse to "unknown Christ" language? How is the Church to witness to Christ's presence among the non-Christian poor? Who is Jesus Christ to these masses? Have the Asian poor rejected Jesus because of the distortion of this figure as the spiritual sustainer of the rich?

\subsection{Women's Experience of the Sacred}

In EATWOT's different regions, we are beginning to consider women's vision and praxis. For example, in Latin America it has been said: why is 
it that our different cultures and theologies have needed violence to build themselves up? Why are women the major victims of such violence? Why do cultures need a "scapegoat" and why is this role especially imposed on women? Can we live outside the circle of violence? Can we recognize our relationships according to a different model, or are we condemned only to change the victims. To change the present scapegoat to another one? This is a central question in Christian theology. Jesus is often taken as an innocent scapegoat. What does this theology mean concretely today? Is it the expression of our own historical reality that needs always to sacrifice innocents in order to give "abundant life" to privileged minorities? Do we express the need to endure suffering and forsakenness by having in Jesus the example, the strength, and the hope of changing life?

In Asia it has been asked: what has liberation spirituality to say and to do about sexuality in the Asian setting? What are the Asian churches and liberation theologies doing in the face of the distorted understanding of sexuality? Sexism, a manifestation of patriarchy, is a sin. The concept and reality of sexuality are distorted. But humanity needs to become aware that our ancient cultures view human sexuality in its wholeness. Sexuality stands for beauty and creativity of humans as images of God and portrays mutual need and interdependence. As an authentic basis of common life in community and communion, it is part of human spirituality.

Among US minorities, it has been said: EATWOT members must recognise the importance of lo cotidiano, that is, what happens every day, the struggle for survival that is the daily bread of grass roots women's lives. Women everywhere have been insisting on the importance of $l o$ cotidiano as a theological category. It is precisely lo cotidiano which is at the heart of the civil society to which Latin American liberation theologians have now turned. Moreover, lo cotidiano is the epistemological framework of our theological enterprise. The daily experience of the poor and oppressed, not only points to their capacity to know but also highlights the features of their knowing. Of course there are other ways of coming to know what is real; there are many types of knowledge.

African women have been saying: our Association needs to undergo a cultural revolution with regard to its understanding of the humanity of women. The entrenched machistic relationship between men and women has to be exorcised. The Mende of Sierra Leone and the Yoruba of Nigeria have to teach EATWOT that "if a man sees a snake and a woman kills it nothing is lost". The needed task has been accomplished. The Association of Third World Theologians has to stop behaving like the Akan of Ghana who say: "while the male soul is alive, the female soul does not have to 
crack nuts". The traditional reasons for assigning strict division of labour and gender roles have no unchanging validity. Accepting this intellectually, however, is not as difficult as learning to live by it. Cross-gender intercontinental dialogue on women is yet to become a part of EATWOT process.

\section{WALKING ONWARDS: THE FUTURE}

The term Third World remains the official identity of EATWOT; its meaning primarily arises from the social, economic, political religious, cultural forces which render Third World persons expendable people.

EATWOT will continue to be a forum closely linked to people and their struggle for life and dignity, and, it offers space for wide net-working and deeper reflection and articulation of their experiences, through their own languages and wisdom.

EATWOT will open up more fully and respectfully to indigenous and aboriginal people, supporting their struggles through reflection and participation in all possible ways.

To realize our ecumenicity more fully, EATWOT will involve people of other faiths and secular ideologies in dialogue and common action for justice, rights, and liberation.

Women's theologies and hermeneutics, women's experiences of the divine, their symbolic expressions, as well as ecological issues, will be respected and taken seriously, and allowed to transform and restructure all of EATWOT's concerns, approaches, struggles, discourses.

\section{NOTES:}

1 This is a report on the Fourth General Assembly of the Ecumenical Association of Third World Theologians (EATWOT) held in Tagaytay City (the Philippines) on December 10-17, 1996.

The Ecumenical Association of Third World Theologians was born in Dar es Salaam on August 12,1976. Adopting a provisional constitution, the founding members defined the association's aim as the continuing development of Third World Christian theologies which will serve the church's mission in the world and witness to the new humanity in Christ expressed in the struggle for a just society (V Fabella, Beyond Bonding, Manila, Raintree Publishing Inc 1993).

2 Genesis 1 \& 2; Revelation $21 \& 22$.

$3 \quad$ Numbers 27.

$4 \quad$ I Kings 12.

5 Leviticus 25; Isaiah 61.

6 Amos; Ezekiel 34; Isaiah.

7 The synoptic gospels bring out this concept succintly to the fore. 
8 John 17; Matthew 6:9-13; Luke 11:1-4.

9 Acts 5.

10 Luke 1:46-55.

11 For the past five years, the Women Commission activities were granted over one-third of EATWOT budget. Their projects resulted in the publication of several books among which the following were major ones:

M J Manazan, M A Oduyoye et al (eds), Women Resisting Violence, Maryknoll, Orbis Books 1996.

V Fabella, Beyond Bonding, Manila, Raintree Publishing Inc 1993.

J A Gallares, Images of Faith, Philippines, Clarentian Publications 1992.

12 We have in mind that methods can be used as means of control and manipulation. The following understandings of method have emerged. Our theological method must clearly indicate our fundamental commitment to liberation, to articulate God's self-revelation among the poor and oppressed who seek justice. Socio-economic, political, gender and religio-cultural analysis are elements of contextualization that need to be present in all our theological articulations. The understanding and denunciation of the many faces of oppression (exploitation, marginalization, powerlessness, violence) has to be taken into account in our theological work. Our methods of thinking must give special attention to the experiences and understandings of women, indigenous people, dalits, peasants, and to ecological concerns. These are not issues to be added on, but rather key dimensions in all our reflection.

13 The Christian faith was expressed in Graeco-Roman categories and later these were absolutised by the Councils of Nicea (325) and Chalcedon (451) during the Trinitarian and Christological controversies, according to Asian theologians who were present at the General Assembly. They pointed out that theology, constructed on the limited context of Europe was considered to be the universal truth valid for all people of all times and places. It is therefore maintained that Western Christologies cannot be relevant to Asian Christologies. 